\title{
Development of Chromium(III) Selective Potentiometric Sensor by Using Synthesized Triazole Derivative as an Ionophore
}

\author{
Pankaj Kumar, ${ }^{1}$ Harish Kumar Sharma, ${ }^{2}$ and Kamaal G. Shalaan ${ }^{2}$ \\ ${ }^{1}$ Department of Chemistry, College of Engineering Studies, University of Petroleum and Energy Studies, Uttarakhand, \\ Dehradun 248007, India \\ ${ }^{2}$ Department of Chemistry, Maharishi Markandeshwar University, Mullana, Haryana, Ambala 133203, India
}

Correspondence should be addressed to Pankaj Kumar; pkumar@ddn.upes.ac.in

Received 29 June 2012; Accepted 28 August 2012

Academic Editor: Arturo Espinosa

Copyright (C) 2013 Pankaj Kumar et al. This is an open access article distributed under the Creative Commons Attribution License, which permits unrestricted use, distribution, and reproduction in any medium, provided the original work is properly cited.

\begin{abstract}
A new poly(vinyl chloride) membrane based electrochemical sensor containing synthesized triazole compound, that is, bis(4-N-amino-5-mercapto-1,2,4-triazol-3-yl)alkane (BAMTA) as an electroactive material was prepared and investigated as a chromium(III) selective sensor. The optimum composition of the best performing membrane contained triazole, sodium tetraphenylborate (NaTPB), nitrophenyl octyl-ether (NPOE), and polyvinyl-chloride (PVC) in the ratio 10:2:50:38 w/w. The sensor exhibited near Nernstian slope of $19.8 \pm 0.2 \mathrm{mV} /$ decade of activity in the working concentration range of $1.0 \times 10^{-5}-1.0 \times$ $10^{-1} \mathrm{M}$. It displayed a stable potential response in the $\mathrm{pH}$ range 3.4-5.2. The sensor exhibited a fast response time of less than $10 \mathrm{~s}$ and could be used for at least 6 weeks without any considerable divergence in potentials. The proposed sensor showed very good selectivity over most of the common cations including $\mathrm{Li}^{+}, \mathrm{K}^{+}, \mathrm{Na}^{+}, \mathrm{Ni}^{2+}, \mathrm{Co}^{2+}, \mathrm{Cu}^{2+}, \mathrm{Sr}^{2+}, \mathrm{Ba}^{2+}, \mathrm{Cs}^{+}, \mathrm{Pb}^{2+}, \mathrm{Zn}^{2+}, \mathrm{Mg}^{2+}, \mathrm{Cd}^{2+}, \mathrm{Al}^{3+}$, $\mathrm{Fe}^{3+}$, and $\mathrm{La}^{3+}$. It could be employed successfully for the determination of $\mathrm{Cr}$ (III) ion activity in electroplating and leather tanning industry wastes.
\end{abstract}

\section{Introduction}

Chromium finds its widespread use in steel manufacturing, leather tanning, wood treatment, electroplating, paint and pigment, metal finishing, and alloy manufacturing industries. Chromium is essential for carbohydrate and fat metabolism. Its deficiency may lead to diabetes and cardio-vascular diseases. The estimated safe and adequate daily dietary intake for chromium in adults is $50-200 \mu \mathrm{g}$ per day $[1,2]$. On the other, hand it is well known for its carcinogen effects. Its high concentration can also cause epigastria pain, nausea, vomiting, diarrhea, and hemorrhage. Due to the vital importance of $\mathrm{Cr}(\mathrm{III})$ in complex biological systems and industrial systems, environmental and industrial samples, the development of a new selective and sensitive method for its quick estimation is a challenging goal. Although sophisticated analytical techniques like atomic absorption spectrometry (AAS), X-ray fluorescence (XRF), high performance liquid chromatography (HPLC), and inductively coupled plasma-atomic emission spectroscopy (ICP-AES) have been generally employed for the trace level determination of metals, yet these techniques are disadvantageous in terms of routine analysis and cost. Potentiometric monitoring offers many advantages such as simple instrumentation, speed and ease of preparation, low cost, online monitoring, wide dynamic range, good selectivity, and nondestructive analysis. Due to these advantages a number of ion-selective electrodes have been reported in the recent past and the list is continuously growing tremendously.

Different types of electroactive materials have been used by researchers to develop chromium(III) ion-selective electrodes. Some of them are 4-dimethylaminoazobenzene [3], 1-(2-(1H-imidazole-1-yl)-1-(4-methoxyphenyl) ethylidene)-2-phenyl hydrazine [4], 1-[(2-hydroxy ethyl) amino]-4-methyl-9H-thioxanthen-9-one [5], 4-amino-3-hydrazino-6-methyl-1,2,4-triazin-5-one [6], 2-acetylpyridine [7], $N$-(1-thien-2-ylethylidene)benzene-1,2-diamine [8], 5-amino-1-phenyl-1H-pyrazole-4-carboxamide [9], tributyl phosphate [10], $N$-(acetoacetanilide)-1,2-diaminoethane and $N, N^{\prime}$-bis(acetoacetanilide)-triethylenetetramine [11], 
glyoxal bis(2-hydroxyanil) [12], oxalic acid bis(cyclohexylidene hydrazine) [13], tri-o-thymotide [14], Aurin TCA [15], and p-(4-Acetanilidazo)calix[4] arene [16].

Diverse ionophores have been introduced for the fabrication of cation selective electrodes which include crown ethers, calixarenes, porphyrins, metal chelates and ligands, Schiff's bases, and macrocyclic compounds. These compounds are a category of supramolecular receptors exhibiting rigid cavities, generally in a molecular recognition. A large variety of cation substrates can be complexed by such heterocyclic structures due to the various available cavity sizes and this property of these compounds has been largely exploited for the development of a number of cation selective electrodes. This efficiency depends on the lipophilicity, conformational flexibility, and high mobility. Triazole, which is appropriately designed, exhibits a large variety of functions for example, inclusion compounds, selective complexing agents for metal ions, and catalysts.

Here we report for the first time a new, highly selective, and a sensitive $\mathrm{Cr}$ (III) electrode based on a synthesized, triazole derivative that is, Bis-(4-N-amino-5-mercapto1,2,4-triazol-3-yl)alkane as an excellent neutral carrier for chromium(III) ions. This suitability has been further confirmed as the PVC membrane electrodes containing triazoles, shown a highly selective behavior towards $\mathrm{Cr}$ (III) ions. In the present study, various experimental conditions such as the percentage weight composition of the membrane ingredients and concentration of the internal solution of the developed electrode have been optimized to obtain better detection limit as well as working concentration range.

\section{Experimental}

2.1. Reagents. For the development of ion-selective electrodes high molecular weight PVC (polyvinylchloride) was used as mechanical support and it was purchased from (Fluka, Switzerland) were used without any further treatment. Triazole derivate was synthesized and characterized by following the procedure reported elsewhere [17]. Tetra hydrofuran (THF) as solvent was purchased from (Merck, India) and $\mathrm{Cr}\left(\mathrm{NO}_{3}\right)_{3}, \mathrm{NiCl}_{2}, \mathrm{Ca}\left(\mathrm{NO}_{3}\right)_{2}, \mathrm{CoCl}_{2}, \mathrm{KCl}, \mathrm{MnCl}_{2}$, $\mathrm{LiNO}_{3}, \mathrm{AgNO}_{3}$, and $\mathrm{Pb}\left(\mathrm{NO}_{3}\right)_{2}$ from (RANKEM, India), $\mathrm{NaCl}, \mathrm{ZnCl}_{2}, \mathrm{CuCl}_{2}$ from (CDH, India), $\mathrm{HgCl}_{2}, \mathrm{CdCl}_{2}$, and EDTA from (QULIKEMS, India). Metal ion solutions were prepared in doubly distilled water and standardized by appropriate methods. Plasticizers nitrophenyl octyl ether (NPOE), dibutylbutyl phosphonate (DBBP), dibutyl phthalate (DBP), tris-(2-ethylhexyl)phosphate (TEP) and tri-butyl phosphate (TBP), and 1-chloro naphthalene (1-CN) were obtained from (Mobil, USA) and sodium tetraphenylborate (NaTPB) from (BDH, UK). Metal salt (nitrate and chloride) solutions were prepared in doubly distilled water and standardized wherever necessary. The chemical characterization of the synthesized compound was carried out by the spectroscopic methods. The obtained results were similar to those already reported. These additives affected the performance of membrane almost in each case. Varying amounts of these compounds were added to the ionophore, PVC, and THF solution prior to pouring it into the acrylic rings. The ratio of membrane ingredients was optimized after a good deal of experimentation.

Best efforts were made to prepare a membrane that generates reproducible and stable potentials. Conditioning of all the membranes was done with $0.1 \mathrm{M} \mathrm{Cr}^{3+}$ solution. The minimum time required for conditioning was 48 hours otherwise the membranes produced unstable potentials. The potential measurements were carried out using the following cell setup at $25 \pm 0.1^{\circ} \mathrm{C}$. Internal reference electrode Ag$\mathrm{AgCl} /$ Internal solution $0.1 \mathrm{M}$ chromium nitrate/PVC membrane/test solution/External reference electrode Ag- $\mathrm{AgCl}$. The concentration of the metal ion in the test solutions varied from $1.0 \times 10^{-6}$ to $1.0 \times 10^{-1} \mathrm{M}$. All the standard metal ion solutions were prepared by serial dilution with $1.0 \times 10^{-1} \mathrm{M}$ as stock solution. At equilibrium, the membrane potential is mainly dependent on the concentration of the target ion outside the membrane and is described by the Nernst equation. Each solution was stirred and potential readings were recorded. These potential values were plotted against negative logarithmic values of chromium ion activity to obtain the standard calibration curve.

2.2. Equipments. ELICO LI $120 \mathrm{pH}$ meter was used as millivoltmeter and a digital $\mathrm{pH}$ meter from (FLORA) to calculate the $\mathrm{pH}$ value of solutions prepared. Silver-silver chloride electrodes were used as reference electrodes.

2.3. Preparation of Membranes. The ionophore triazole derivative, anion excluder sodium tetraphenylborate (NaTPB), plasticizers were taken in constant amounts in the ratio $10: 2: 50: 38 \mathrm{w} / \mathrm{w}$ with an appropriate amount of THF solvent. The mixture was vigorously shaken and after removing the air bubbles, it was poured into rings made of polyacrylate, which were placed on a smooth glass plate. The solution was allowed to evaporate in closed environment at room temperature. After 48 hours, transparent membranes of $5 \mathrm{~mm}$ diameter were cut, attached to a pyrex glass tube with the help of araldite and immersed in different metals ion solutions for equilibration. The ratio of membrane ingredients was optimized after a good deal of experimentation to provide membranes, which generate reproducible results, low noise, and stable potentials. The membranes prepared above were equilibrated in metal ion solutions of constant concentrations for different periods of time. Satisfactory equilibration was achieved with $0.1 \mathrm{M}$ metal ion solutions in a contact time of 2 days. Plasticizers are known to improve the response of membrane by providing a smooth surface, high dielectric constant, homogeneity and improving of the membrane by creating liquid channels in the hydrophobic environment under the membrane. Thus, the response of the membrane improves a lot. On the other hand, anion excluder, that is, NaTPB supervises the activity of anion and ensures that generated partial gradient must be dependent only on the concentration difference of the metal ion present on both sides of the membrane. The effects of solvent mediators and anion excluder were investigated by adding different amounts of these compounds to the membrane solution before pouring it to acrylic rings. 


\section{Results and Discussion}

3.1. Selection of the Membrane. In preliminary experiments, the synthesized ionophore was used as a neutral carrier to prepare PVC based membranes and was tried to determine various metal ions. A number of membrane electrodes were prepared and conditioned in $0.1 \mathrm{M}$ solution of different metal ion solutions, namely, $\mathrm{Li}^{+}, \mathrm{K}^{+}, \mathrm{Na}^{+}, \mathrm{Ni}^{2+}, \mathrm{Co}^{2+}, \mathrm{Cu}^{2+}, \mathrm{Sr}^{2+}$, $\mathrm{Ba}^{2+}, \mathrm{Cs}^{+}, \mathrm{Pb}^{2+}, \mathrm{Zn}^{2+}, \mathrm{Mg}^{2+}, \mathrm{Cd}^{2+}, \mathrm{Al}^{3+}, \mathrm{Fe}^{3+}$, and $\mathrm{La}^{3+}$ ion solutions for 2-3 days. The best potential response of the electrode was recorded for $\mathrm{Cr}^{3+}$ ions while all other ions exhibited lower potential response or no response at all. $\mathrm{Cr}$ (III) ions could interact with the ionophore to form a better complex with the electron rich cavity in the comparison of the bivalent cations. This may be due to its higher charge and suitability which facilitated its attachment to the ionophore in a better way. Further, the rapid exchange kinetics of the resulting ligand-metal ion complex is responsible for the selective behavior of the ionophore towards $\mathrm{Cr}^{3+}$ in comparison to the other trivalent metal ions. Therefore, this membrane was used to develop a chromium(III) ionsselective electrode. It is well known that some additives like anion excluders are useful as these compounds enhance the sensitivity and selectivity of cation selective membrane by reducing its resistance [18]. Also, in case of PVC based neutral carrier membranes, plasticizers if compatible with the ionophore, can provide a smooth surface to the membrane and thus enhance the response characteristics. Although the role of plasticizers is not very firmly established till date but it is assumed that these additives enhance the homogeneity of the PVC based membranes and provide liquid channels within the membrane which facilitates the movement of charge carriers, which ultimately improves the response time and the sensitivity of the membranes. It can also improve the dielectric constant of the polymeric membrane and also the movement of ionophore and its metal complex $[19,20]$ Therefore, the effect on the performance of the membrane after the addition of anion excluder, sodium tetraphenylborate (NaTPB) and plasticizers DBP, DBBP, TEP, TBP, 1-CN, and NPOE was also studied. The ratio of membrane ingredients, time of contact, and concentration of equilibrating solution was optimized so that the membrane could develop reproducible, noiseless, and stable potentials. Membrane to membrane reproducibility was assured by carefully following the optimum conditions of fabrication.

3.2. Working Concentration Range and Slope. The potential response of the electrochemical cells with $0.1 \mathrm{M} \mathrm{Cr}^{3+}$ as internal solution inside the indicator electrode was determined in the range $1.0 \times 10^{-6}$ to $1.0 \times 10^{-1} \mathrm{M} \mathrm{Cr}^{3+}$ solution and depicted in Figure 1. The best working concentration range obtained for NPOE that is, $1.0 \times 10^{-5}-1.0 \times 10^{-1} \mathrm{M}$ with a slope of $19.8 \mathrm{mV}$ / decade of activity. The effect of the addition of other plasticizers that is, DBP, DBBP, TEP, TBP, and 1$\mathrm{CN}$ was not significant on the response properties of the membrane. Further, as the response characteristics of any membrane depend on the amount of ionophore, the effect of changing quantity of ionophore was also studied. If the

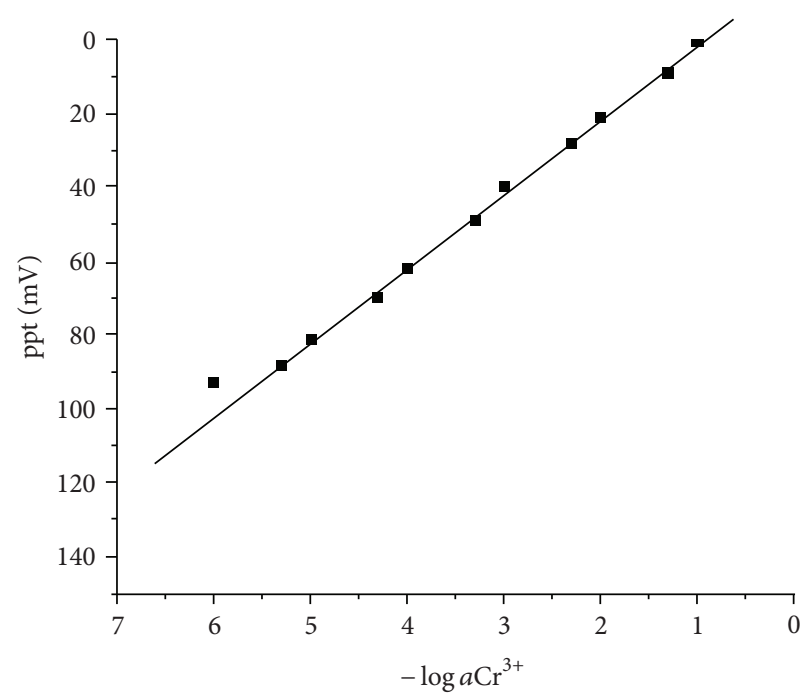

FIgURE 1: Potentiometric response of the PVC membrane sensor based on triazole.

amount of ionophore is less than the above-mentioned ratio, it affects the working concentration range adversely, although the effect on slope is not considerable. If the amount is increased further, it shows no improvement in any of the characteristics of the electrode.

3.3. Effect of the Concentration of Internal Solution on the Response of Sensor. The performance of the electrode was analyzed by using three different concentrations of $\mathrm{Cr}$ (III) ions as the internal solution, that is, $1.0 \times 10^{-1}, 1.0 \times 10^{-2}$ and $1.0 \times 10^{-3} \mathrm{M}$. The best results regarding working concentration range and slope were obtained with an internal solution of activity $1.0 \times 10^{-1} \mathrm{M}$. Therefore, an internal solution of $\mathrm{Cr}^{3+}$ ion activity $1.0 \times 10^{-1} \mathrm{M}$, was used throughout the studies.

3.4. Potentiometric Selectivity. The influence of interfering ions on the response behavior of ion-selective membrane electrodes is usually described in terms of selectivity coefficients. The fixed interference method and the mixed solution method are among the most commonly used to determine the selectivity coefficient of the sensors. However, these methods suffer some limitations if ions of unequal charges are involved. Thus, in this work we followed the matched potential method (MPM), which is totally independent of the Nicolsky-Eisenman equation and also the varying charge of interfering ions. According to MPM, primary ions (A), in a specified activity, are added to a reference solution containing fixed concentration of primary ions and the potential change is recorded. In a separate experiment, interfering ions (B) are successively added to an identical reference solution, until the measured potential matched the one obtained before by adding primary ions. A value of selectivity coefficient equal to 1.0 indicates that the sensor responds equally to the primary as well as an interfering ion. However, a value smaller than 1.0 indicates that the membrane sensor is 
TABLE 1: Potentiometric selectivity coefficient values $\left(\mathrm{K}_{\mathrm{Cr}^{3+} \cdot \mathrm{E}}^{\mathrm{pot}}\right)$ (interfering ions B), observed for the fabricated $\mathrm{Cr}^{3+}$ selective electrode, using matched potential method.

\begin{tabular}{lc}
\hline Interfering ion B & Matched potential method \\
\hline $\mathrm{Li}^{+}$ & $1.0 \times 10^{-3}$ \\
$\mathrm{Na}^{+}$ & $3.2 \times 10^{-3}$ \\
$\mathrm{~K}^{+}$ & $7.0 \times 10^{-3}$ \\
$\mathrm{Ni}^{2+}$ & $4.9 \times 10^{-3}$ \\
$\mathrm{Co}^{2+}$ & $9.0 \times 10^{-3}$ \\
$\mathrm{Cu}^{2+}$ & $1.1 \times 10^{-2}$ \\
$\mathrm{Mg}^{2+}$ & $4.1 \times 10^{-2}$ \\
$\mathrm{~Pb}^{2+}$ & $6.2 \times 10^{-2}$ \\
$\mathrm{Sr}^{2+}$ & $1.6 \times 10^{-2}$ \\
$\mathrm{Ba}^{2+}$ & $8.1 \times 10^{-2}$ \\
$\mathrm{Zn}^{2+}$ & $2.7 \times 10^{-3}$ \\
$\mathrm{Cd}^{2+}$ & $3.9 \times 10^{-2}$ \\
$\mathrm{Mn}^{2+}$ & $8.7 \times 10^{-3}$ \\
$\mathrm{La}^{3+}$ & $1.0 \times 10^{-3}$ \\
$\mathrm{Fe}^{3+}$ & $6.8 \times 10^{-3}$ \\
$\mathrm{Al}^{3+}$ & $2.7 \times 10^{-3}$ \\
\hline
\end{tabular}

responding more to the primary ion than an interfering ion and in such a case the sensor is said to be selective to the primary ion over interfering ions. Further, smaller the selectivity coefficient, higher is the selectivity order. The MPM selectivity coefficient, $K_{\mathrm{A}, \mathrm{B}}^{\mathrm{MPM}}$, is given by the resulting primary ion to interfering ion activity (concentration) ratio

$$
K_{\mathrm{A}, \mathrm{B}}^{\mathrm{MPM}}=\frac{\left(a_{\mathrm{A}}-a_{\mathrm{A}^{\prime}}\right)}{a_{\mathrm{B}}} .
$$

The values of $a_{\mathrm{A}}$ and $a_{\mathrm{A}^{\prime}}$ were taken to be $1.0 \times 10^{-3}$ and $5 \times 10^{-3} \mathrm{M}$, whereas the value of $a_{\mathrm{B}}$ was experimentally determined. The experimental conditions employed and the resulting values are given in Table 1. It is clear from the obtained data, that selectivity coefficient values are much smaller than 1 for almost all the mono-, di-, or trivalent caions. Hence, the electrode shows good selectivity towards chromium(III) ions over other cations.

3.5. $p H$ Range. $\mathrm{pH}$ dependence of the proposed ion-selective electrode was studied over the $\mathrm{pH}$ range 2.0-8.0 at the $1.0 \times$ $10^{-3} \mathrm{M} \mathrm{Cr}^{3+}$ concentration after adjusting the $\mathrm{pH}$ of the solutions with $\mathrm{HNO} 3$ and $\mathrm{NaOH}$. It is clear that the potential remained constant in the $\mathrm{pH}$ range (3.4-5.2), which can be considered as the working $\mathrm{pH}$ range of the proposed sensor (Figure 2). Above this $\mathrm{pH}$ range, a sharp decrease in potentials may be attributed to the hydrolysis of chromium ions and formation of some soluble or insoluble hydroxyl complexes while for $\mathrm{pH}$ values below this range, the decrease in potentials may be due to the influence of hydrogen ions flux.

3.6. Potentiometric Titration. The sensor was tried successfully for the end point determination in the potentiometric

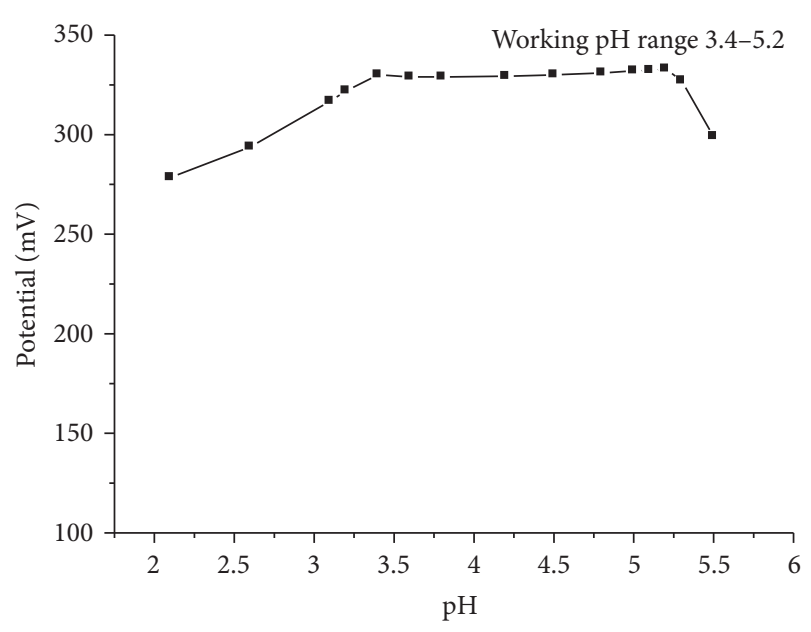

FIgURE 2: Effect of $\mathrm{pH}$ on the cell potential of electrode.

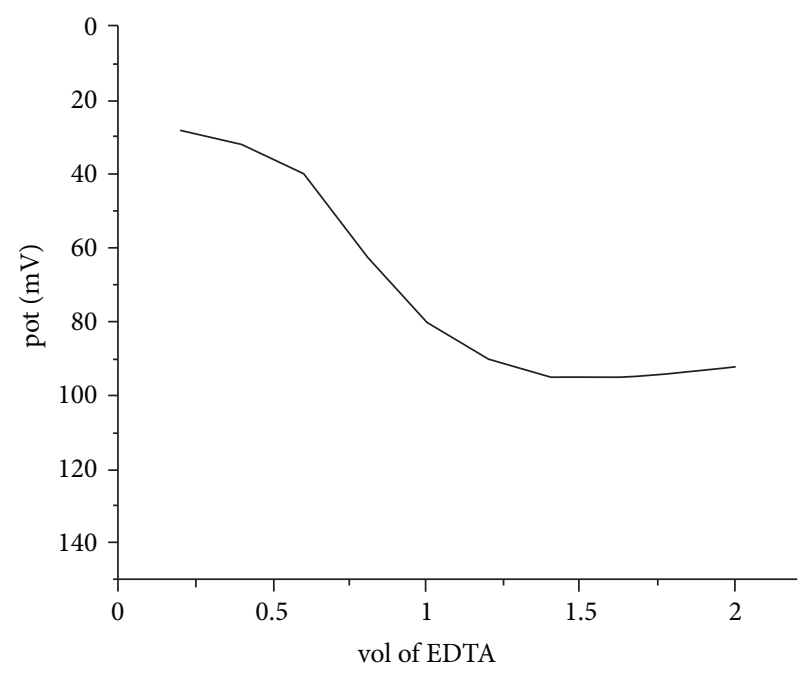

FIGURE 3: Potentiometric plot for the titration of Cr(III) $1.0 \times 10^{-2} \mathrm{M}$ $(10 \mathrm{~mL})$ against EDTA $\left(1.0 \times 10^{-1} \mathrm{M}\right)$.

titration of $\mathrm{Cr}^{3+}$ against EDTA solution. A $10 \mathrm{~mL}$ of $1.0 \times$ $10^{-2} \mathrm{M}$ solution of $\mathrm{Cr}^{3+}$ was titrated against $1.0 \times 10^{-1} \mathrm{M}$ EDTA solution at $\mathrm{pH} 4.4$ The conventional sigmoid shape plot was obtained and the sharp break point corresponds to the stoichiometry of $\mathrm{Cr}(\mathrm{III})$-EDTA complex and indicates the end point of titration (Figure 3) [21].

3.7. Analytical Application. The proposed sensor has been successfully used for determining chromium ions in six real samples. Three were obtained from a nearby electroplating industry at the interval of seven days and another three from a lather tanning industry in a similar fashion. The samples were collected, filtered, and stored in plastic bottles and were analyzed within 2 hours after the collection. Their $\mathrm{pH}$ was adjusted at 4.0 by using $0.1 \mathrm{MHNO}_{3}$ and hexamine. These samples were pretreated to convert $\mathrm{Cr}(\mathrm{VI})$ to $\mathrm{Cr}(\mathrm{III})$, if present any by following the reported method [22]. The obtained data indicates that the amount of chromium determined in effluent by using the proposed sensor is in close 
TABLE 2: Cr(III) concentration as determined by the proposed potentiometric sensor as well as by atomic absorption spectrophotometer.

\begin{tabular}{lcccc}
\hline Sample no. $\mathrm{pH}$ found & $\mathrm{pH}$ adjusted at & $\begin{array}{c}\mathrm{Cr}(\mathrm{III}) \text { activity as determined by the proposed sensor (ppm) } \\
\text { (Standard deviation } \pm 0.1)\end{array}$ & $\begin{array}{c}\text { Cr(III) activity as determined by } \\
\text { AAS (ppm) }\end{array}$ \\
\hline 1 & 2.6 & 3.0 & 5.6 & 5.7 \\
2 & 2.2 & 3.0 & 6.5 & 6.4 \\
3 & 2.6 & 3.0 & 6.9 & 7.0 \\
4 & 4.4 & 3.0 & 14.0 & 13.8 \\
5 & 5.2 & 3.0 & 13.6 & 13.7 \\
6 & 5.8 & 3.0 & 11.8 & 11.6 \\
\hline
\end{tabular}

All the observations are the average value for four readings recorded for the same sample.

TABLE 3: Comparison of proposed Chromium(III) selective electrode with some of the earlier reported electrodes.

\begin{tabular}{|c|c|c|c|c|c|c|}
\hline Ionophore used & $\begin{array}{l}\text { Working concentration } \\
\text { range }(\mathrm{M})\end{array}$ & $\begin{array}{l}\text { Detection limit } \\
(\mathrm{M})\end{array}$ & $\begin{array}{l}\text { Working } \\
\text { pH range }\end{array}$ & Interference & $\begin{array}{l}\text { Response } \\
\text { time (s) }\end{array}$ & Reference no. \\
\hline 4-dimethylaminobenzene & $1.66 \times 10^{-6}-1.0 \times 10^{-2}$ & $8.0 \times 10^{-7}$ & $3.0-5.5$ & $\mathrm{Cu}^{2+}, \mathrm{Ag}^{+}, \mathrm{Fe}^{3+}$ & 10 & {$[3]$} \\
\hline $\begin{array}{l}N, N^{\prime} \text {-bis(acetoacetanilide) } \\
\text { Triethylenetetramine }\end{array}$ & $8.3 \times 10^{-7}-1.0 \times 10^{-1}$ & $6.3 \times 10^{-7}$ & $2.0-5.5$ & No interference & 22 & {$[11]$} \\
\hline Glyoxal bis(2-hydroxyanil) & $3.0 \times 10^{-6}-1.0 \times 10^{-2}$ & $6.3 \times 10^{-7}$ & $2.7-6.5$ & $\mathrm{Zn}^{2+}$ & 20 & {$[12]$} \\
\hline $\begin{array}{l}\text { Oxalic acid bis(cyclohexylidene } \\
\text { Hydrazide }\end{array}$ & $1.0 \times 10^{-7}-1.0 \times 10^{-2}$ & $6.3 \times 10^{-7}$ & $1.7-6.5$ & $\mathrm{Cd}^{2+}, \mathrm{Ni}^{2+}$ & 20 & {$[13]$} \\
\hline Tri-o-thymotide & $4.0 \times 10^{-6}-1.0 \times 10^{-1}$ & $2.0 \times 10^{-7}$ & $2.8-5.1$ & $\mathrm{Na}^{+}, \mathrm{Cd}^{2+}$ & 15 & {$[14]$} \\
\hline p-(4-acetanilidazo)calix[4]arene & $9.8 \times 10^{-7}-1.0 \times 10^{-1}$ & $7.3 \times 10^{-7}$ & $2.8-5.7$ & No interference & 14 & [15] \\
\hline Aurin TCA & $7.0 \times 10^{-6}-1.0 \times 10^{-1}$ & Not mentioned & $3.5-6.5$ & $\mathrm{Na}^{+}, \mathrm{Zn}^{2+}, \mathrm{Pb}^{2+}$ & 10 & {$[16]$} \\
\hline $\begin{array}{l}\text { 1-[(2-hydroxy ethyl) amino]-4- } \\
\text { methyl-9H-thioxanthen-9-one }\end{array}$ & $3.2 \times 10^{-7}-1.0 \times 10^{-1}$ & $1.6 \times 10^{-7}$ & $4.8-6.3$ & NM & 10 & [5] \\
\hline $\begin{array}{l}\text { 4-amino-3-hydrazino-6-methyl-1,2,4- } \\
\text { triazin-5-one }\end{array}$ & $1.0 \times 10^{-6}-1.0 \times 10^{-1}$ & $5.8 \times 10^{-7}$ & $2.7-6.6$ & NM & 8 & {$[6]$} \\
\hline $\begin{array}{l}N \text {-(1-thien-2-ylethylidene)benzene- } \\
\text { 1,2-diamine }\end{array}$ & $1.0 \times 10^{-6}-1.0 \times 10^{-1}$ & $7.0 \times 10^{-7}$ & $3.0-6.6$ & NM & 15 & {$[8]$} \\
\hline BAMTA & $1.0 \times 10^{-5}-1.0 \times 10^{-1}$ & $8.6 \times 10^{-6}$ & $3.4-5.2$ & No interference & 10 & Proposed work \\
\hline
\end{tabular}

agreement with that determined by the atomic absorption spectrophotometer (Table 2).

It is important to mention that the proposed sensor exhibits superior results than the existing sensors for the selective quantification of chromium(III) ions: this sensor shows better selectivity $[3,12-14,16]$ and better response time $[8,11-15]$. Its working $\mathrm{pH}$ range is also comparable to most of the listed sensors (Table 3 ).

\section{Conclusion}

A new poly(vinyl chloride) membrane containing bis-(4-Namino-5-mercapto-1,2,4-triazol-3-yl)alkane as a membrane carrier, was used to fabricate a chromium(III) selective electrode. The optimum composition of the best performing membrane contained triazole: NaTPB:NPOE:PVC in the ratio $10: 2: 50: 38(\mathrm{w} / \mathrm{w})$. This electrode exhibited a near Nernstian slope of $19.8 \pm 0.2 \mathrm{mV} /$ decade of activity in the working concentration range of $1.0 \times 10^{-5}-1.0 \times 10^{-1} \mathrm{M}$. This sensor works nicely in the $\mathrm{pH}$ range $3.4-5.2$ as there is no change in observed potential of a fixed concentration of $\mathrm{Cr}$ (III). This electrode showed very good selectivity over most of the common cations which are generally present in real samples. It could be used for the determination of $\mathrm{Cr}$ (III) concentration in the industrial waste samples as well as an indicator electrode in the potentiometric titration of $\mathrm{Cr}$ (III) ion against EDTA solution. The results show that the proposed sensor can be considered as a good addition in the existing list of $\mathrm{Cr}$ (III) selective sensors.

\section{References}

[1] National Research Council, Recommended Dietary Allowance, National Academy Press, Washington, DC, USA, 10th edition, 1989.

[2] D. E. Kimbrough, Y. Cohen, A. M. Winer, L. Creelman, and C. Mabuni, "A critical assessment of chromium in the environment," Critical Reviews in Environmental Science and Technology, vol. 29, no. 1, pp. 1-46, 1999.

[3] A. Abbaspour and A. Izadyar, "Chromium(III) ion-selective electrode based on 4-dimethylaminoazobenzene," Talanta, vol. 53, no. 5, pp. 1009-1013, 2001. 
[4] A. Abbaspour, M. Refahi, A. Khalafi-Nezhad, N. S. Rad, and S. Behrouz, "Carbon composite-PVC based membrane coated platinum electrode for chromium determination," Journal of Hazardous Materials, vol. 184, no. 1-3, pp. 20-25, 2010.

[5] M. Ghaedi, A. Shokrollahi, A. R. Salimibeni, S. Noshadi, and S. Joybar, "Preparation of a new chromium(III) selective electrode based on 1-[(2-hydroxy ethyl) amino]-4-methyl-9Hthioxanthen-9-one as a neutral carrier," Journal of Hazardous Materials, vol. 178, no. 1-3, pp. 157-163, 2010.

[6] H. A. Zamani, G. Rajabzadeh, and M. R. Ganjali, "Highly selective and sensitive chromium(III) membrane sensors based on 4-amino-3-hydrazino-6-methyl-1,2,4-triazin-5-one as a new neutral ionophore," Sensors and Actuators B, vol. 119, no. 1, pp. 41-46, 2006.

[7] W. Zhou, Y. Chai, R. Yuan, J. Guo, and X. Wu, "Organically nanoporous silica gel based on carbon paste electrode for potentiometric detection of trace Cr(III)," Analytica Chimica Acta, vol. 647, no. 2, pp. 210-214, 2009.

[8] M. R. Ganjali, P. Norouzi, F. Faridbod, M. Ghorbani, and M. Adib, "Highly selective and sensitive chromium(III) membrane sensors based on a new tridentate Schiff's base," Analytica Chimica Acta, vol. 569, no. 1-2, pp. 35-41, 2006.

[9] H. A. Zamani, G. Rajabzadeh, M. Masrornia, A. Dejbord, M. R. Ganjali, and N. Seifi, "Determination of $\mathrm{Cr}^{3+}$ ions in biological and environmental samples by a chromium(III) membrane sensor based on 5-amino-1-phenyl-1H-pyrazole-4carboxamide," Desalination, vol. 249, no. 2, pp. 560-565, 2009.

[10] A. Zazoua, R. Kherrat, M. H. Samar et al., "Characterization of TBP containing polysiloxane membrane/insulator/ semiconductor structures for hexavalent chromium detection," Materials Science and Engineering C, vol. 28, no. 5-6, pp. 1014-1019, 2008.

[11] A. K. Singh, V. K. Gupta, and B. Gupta, "Chromium(III) selective membrane sensors based on Schiff bases as chelating ionophores," Analytica Chimica Acta, vol. 585, no. 1, pp. 171-178, 2007.

[12] M. B. Gholivand and F. Sharifpour, "Chromium(III) ion selective electrode based on glyoxal bis(2-hydroxyanil)," Talanta, vol. 60, no. 4, pp. 707-713, 2003.

[13] M. B. Gholivand and F. Raheedayat, "Chromium(III) ion selective electrode based on oxalic acid bis(cyclohexylidene hydrazide)," Electroanalysis, vol. 16, no. 16, pp. 1330-1335, 2004.

[14] V. K. Gupta, A. K. Jain, P. Kumar, S. Agarwal, and G. Maheshwari, "Chromium(III)-selective sensor based on tri-othymotide in PVC matrix," Sensors and Actuators B, vol. 113, no. 1, pp. 182-186, 2006.

[15] R. K. Sharma and A. Goel, "Development of a Cr(III)-specific potentiometric sensor using Aurin tricarboxylic acid modified silica," Analytica Chimica Acta, vol. 534, no. 1, pp. 137-142, 2005.

[16] P. Kumar and Y. B. Shim, "Chromium(III)-selective electrode using p-(4-Acetanilidazo)calix[4] arene as an ionophore in PVC Matrix," Bulletin of the Korean Chemical Society, vol. 29, no. 12, pp. 2471-2476, 2008.

[17] M. Al-Amin and M. R. Islam, "Synthesis of some bis-triazole derivatives as probe for cytotoxicity study," Bangladesh Journal of Pharmacolog, vol. 1, pp. 21-26, 2006.

[18] V. K. Gupta, R. Prasad, P. Kumar, and R. Mangla, "New nickel(II) selective potentiometric sensor based on 5,7,12,14tetramethyldibenzotetraazaannulene in a poly(vinyl chloride) matrix," Analytica Chimica Acta, vol. 420, no. 1, pp. 19-27, 2000.
[19] V. K. Gupta, R. N. Goyal, S. Agarwal, P. Kumar, and N. Bachheti, "Nickel(II)-selective sensor based on dibenzo-18-crown-6 in PVC matrix," Talanta, vol. 71, no. 2, pp. 795-800, 2007.

[20] T. Hiroyuki, G. Takuya, and I. Yasuhiko, "Concentration- and concentration ratio-de-pendent selectivity coefficients for ionselctive electrodes," Analytica Chimica Acta, vol. 73, no. 2, p. 328, 1974.

[21] V. K. Gupta, A. K. Jain, L. P. Singh, U. Khurana, and P. Kumar, "Molybdate sensor based on 5,10,15,20-tetraphenylporphyrinatocobalt complex in a PVC matrix," Analytica Chimica Acta, vol. 379, no. 1-2, pp. 201-208, 1999.

[22] M. Pettine, L. Campanella, and F. J. Millero, "Reduction of hexavalent chromium by $\mathrm{H}_{2} \mathrm{O}_{2}$ in acidic solutions," Environmental Science and Technology, vol. 36, no. 5, pp. 901-907, 2002. 

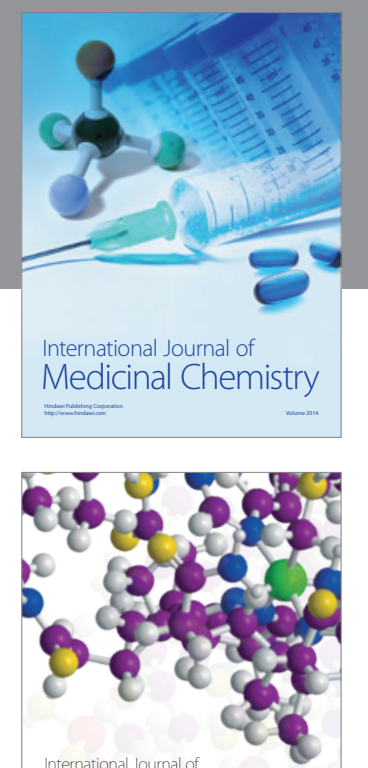

\section{Carbohydrate} Chemistry

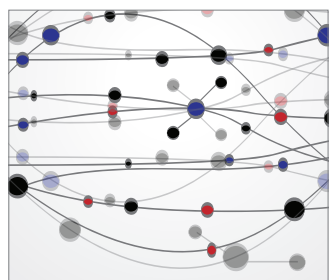

The Scientific World Journal
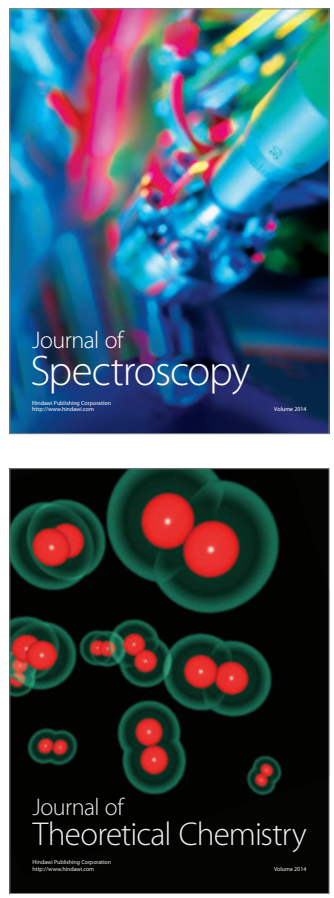
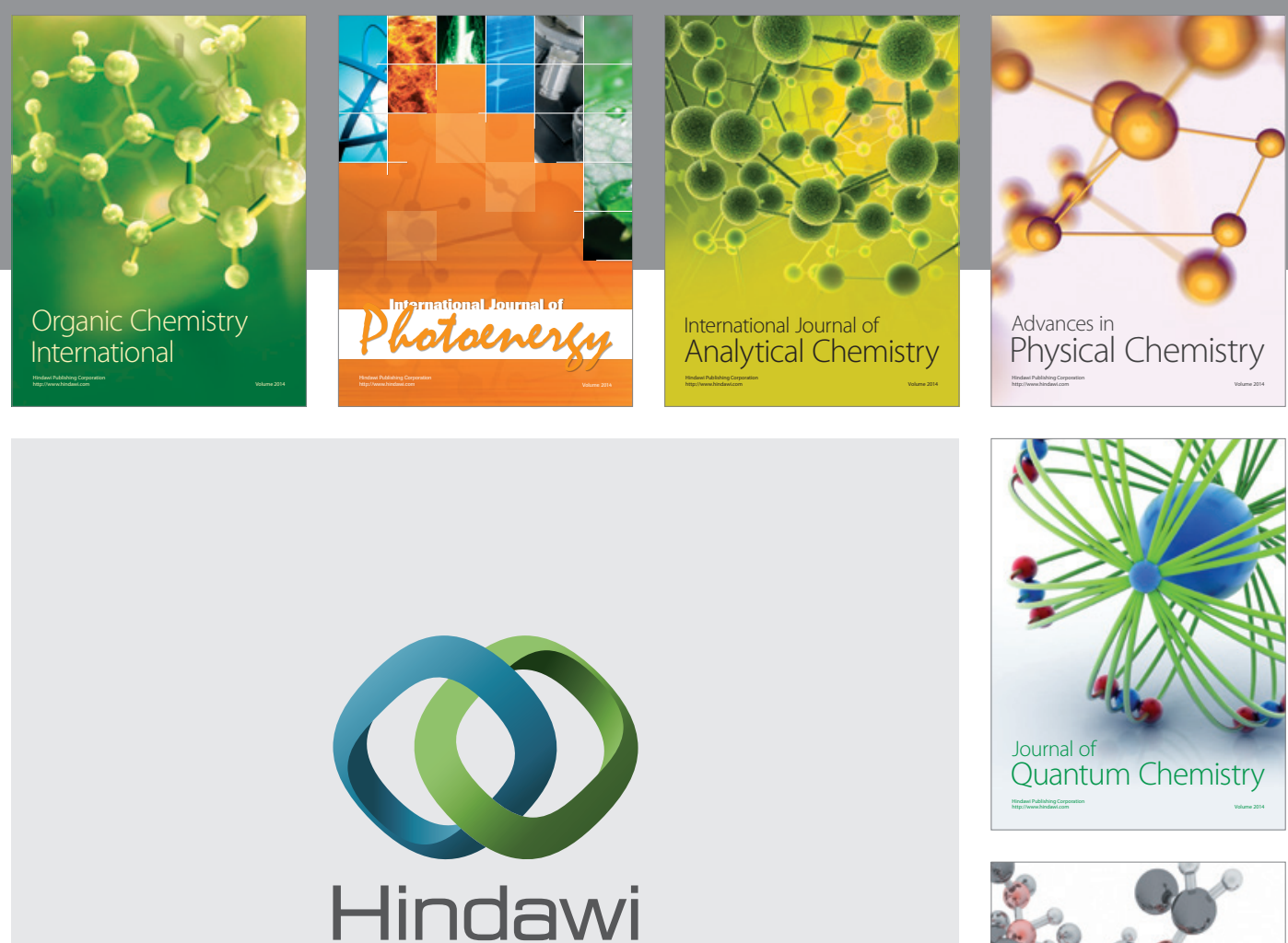

Submit your manuscripts at

http://www.hindawi.com

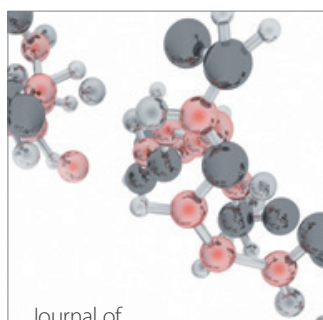

Analytical Methods

in Chemistry

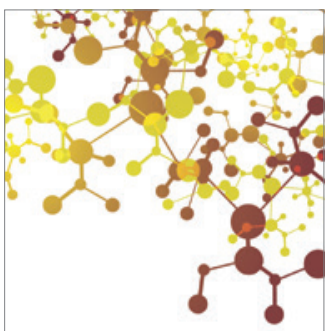

Journal of

Applied Chemistry

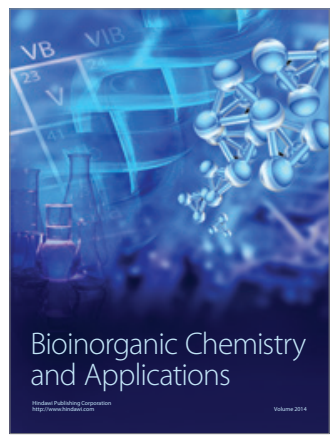

Inorganic Chemistry
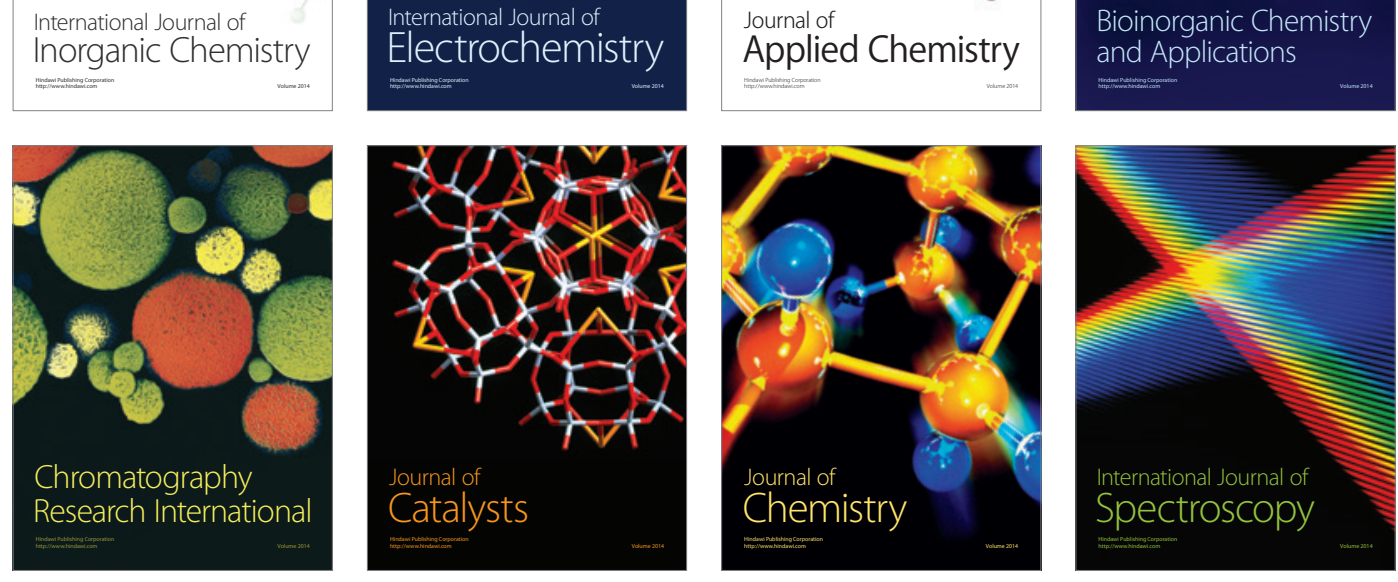